\title{
Subjectivity as a Necessary Component of the Professional Growth of a Specialist in Field of Physical Rehabilitation
}

\section{Суб'єктність як необхідна складова професійного становлення фахівця з фізичної реабілітації}

\author{
Liudmyla Prymachok \\ Ph.D. in Pedagogical Sciences, Assistant Professor, Scientific \\ Institute of Public Health of National University of Water Mana- \\ gement and Nature Usage, Rivne (Ukraine) \\ ORCID ID: https://orcid.org/0000-0002-6591-5223 \\ Researcher ID: F-3874-2019 \\ E-mail: primachok73@ukr.net

\section{Людмила Примачок} \\ Кандидат педагогічних наук, доцент, Навчально-науковий \\ інститут охорони здоров'я Національного університету водного \\ господарства та природокористування, м. Рівне (Україна)
}

\begin{abstract}
In the article the levels of an individual's subjectivity formation are described. The role of subjectivity in the professional activities of a specialist in a field of physical rehabilitation is outlined. The most important characteristics of the subjectivity of a personality of a specialist in a field of physical rehabilitation are identified. The aspects of subjectivity of a specialist in a field of physical rehabilitation are formulated: 1) social aspects are related to the subject's manifestations in terms of social identity, the carrier of social norms, attitudes and features of interactions; 2) acmeological aspects, related to characteristics
\end{abstract}

Address for correspondence, e-mail: kpnu_lab_ps@ukr.net Copyright: (C) Prymachok Liudmyla

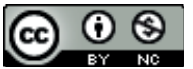

The article is licensed under CC BY-NC 4.0 International

(https://creativecommons.org/licenses/by-nc/4.0/)

(C) Prymachok Liudmyla

DOI (article): https://doi.org/10.32626/2227-6246.2019-46.327-347 
that are manifested purely in the process of professional activity, including the ways of developing the professional competence of a specialist; 3) axiological aspects with the aim to form the axiopsychics of a specialist in a field of physical rehabilitation.

From the point of view of the content of subjectivity of the person, four interrelated blocks are identified in the professional activities of a specialist in a field of physical rehabilitation, and their content is disclosed. It is stated that the motivational-value block contains the motives and goals of the professional activity of a specialist in a field of physical rehabilitation, as well as the structure of the specialist's values. It is emphasized that the intensiveactivity unit is characterized by a combination of the following structural components: the rehabilitologist's abilities and possibilities to solve professional tasks and problems; the ability to collaborate, to see the uniqueness of another person, to be active in establishing contacts. It is emphasized that the reflexiveregulatory block is connected with professional reflection, critical assessment of professional knowledge in a view of the peculiarities of real professional activity of a specialist in a field of physical rehabilitation. It is stated that the creative and operational block contains personal qualities and opportunities for professional development and self-improvement. The concept of "psychotherapeutic responsibility" of a specialist in a field of physical rehabilitation is clarified in the article. It has been stated that psychotherapeutic responsibility in the broadest sense is, first of all, a voluntary decision made from the point of view of a rehabilitologist. It is emphasized that the factor of voluntariness means that the subject independently, in a view of his/her beliefs, directs his / her will, his/her personal resources for the implementation of the decision. It is emphasized that taking psychotherapeutic responsibility means taking the right position, setting and solving high-performing professional tasks and problems.

Key words: subjectivity, professional activity, social aspect, acmeological aspect, axiological aspect, motivational-value block, intentional-activity block, reflexive-regulatory block, creative-operative block, psychotherapeutic responsibility.

\section{Вступ}

Категорія суб’єктності в психології є однією з ключових і пов'язана з поняттям «суб'єкт», яке до свого змісту включає щонайменше три істотні акмеологічні характеристики: необхідність удосконалення, досягнення найвищого рівня (c) Prymachok Liudmyla

DOI (article): https://doi.org/10.32626/2227-6246.2019-46.327-347 
розвитку індивіда, який і означає поняття «суб'єкт»; здатність до самодіяльності, самоорганізації, саморегуляції та самореалізації; «Я-концепція» особистості як уявлення про себе реального, актуалізація своїх реальних і потенційних можливостей (Брушлинский, 1999).

Ці положення є головними для психологічного аналізу процесу розвитку суб'єкта в будь-якій сфері життєдіяльності. Крім того, суб'єктний підхід в акмеології є базовим і припускає розвиток понять «особистість» $\mathrm{i}$ «суб'єкт». Акмеологічне розуміння співвідношення цих понять полягає у твердженні про те, що особистість постає як суб'єкт - стає суб'єктом у процесі життя та професійної діяльності, тобто, людина не $є$ суб'єктом із самого початку. Цей процес відбувається у ході розв'язання протиріч між системою цілей, цінностей, мотивів, вимог, здатностей, системою праці, спілкування, самого життя з його обставинами, ситуаціями, які значною мірою породжують ці протиріччя (Котик, 2000).

Отже, категорія «суб’єкт» є інтегральною, здатною експлікувати психологічне поєднання різних просторів людської діяльності. Як свідчить досвід психологічної науки, саме поняття «суб'єкт» містить також інтегральні характеристики психіки особистості (Михальчук, 2008; Онуфрієва, 2013). Внутрішня інтеграція є органічною якістю суб'єкта, саме в суб'єкті об’єднуються в систему різноманітні психічні процеси і функції. У нашому дослідженні під цим терміном ми розумітимемо самовизначення суб'єкта в системі політичних, соціальних, професійних, внутрішньо-міжособистісних взаємостосунків, які мають суто психологічну природу.

Категорія суб’єкта в психології є також парадигмальною (Hoffman, 1961), оскільки ї̈ теоретико-практичний характер визначається тим, що її предметом постає суб'єкт того чи іншого виду діяльності. Це стосується і професійної діяльності реабілітолога. Можемо з упевненістю наголосити, що становлення особистості фахівця з фізичної реабілітації є процесом формування стійких особистісних якостей, властивостей, (C) Prymachok Liudmyla

DOI (article): https://doi.org/10.32626/2227-6246.2019-46.327-347 
DOI: https://doi.org/10.32626/2227-6246.2019-46

фреймів, необхідних для здійснення професійної діяльності 3 актуалізацією психічних й особистісних властивостей і використання їх як суто особистісних ресурсів і засобів відповідно до вимог та умов професійної діяльності.

Тому мета нашої статті - окреслити психологічні критеpiї суб’єктності, властиві, в тому числі, й фахівцеві з фізичної реабілітації.

\section{Завдання статті}

1. Описати рівні сформованості суб'єктності.

2. Окреслити роль суб’єктності у професійній діяльності фахівця з фізичної реабілітації.

3. Визначити найважливіші характеристики суб'єктності особистості фахівця з фізичної реабілітації.

4. Сформулювати аспекти суб’єктності саме фахівця 3 фізичної реабілітації.

5. Із точки зору змістової характеристики суб'єктності виокремити чотири взаємопов'язані блоки у професійній діяльності реабілітолога, розкрити їх зміст.

6 Уточнити поняття психотерапевтичної відповідальності фахівця з фізичної реабілітації.

\section{Методи дослідження}

Для розв'язання поставлених у роботі завдань використовувалися такі теоретичні методи дослідження: категоріальний, структурно-функціональний, аналіз, систематизація, моделювання, узагальнення.

\section{Результати та дискусії}

Опишемо психологічні критерії суб'єктності. Перший із них, за характеристикою низки дослідників (Абульханова, 1999; Брушлинский, 1999 та ін.), пов’язаний, насалперед, із розв'язаннял різноланітних протиріч. Це - протиріччя між реальним станом, якістю, рівнем розвитку особистості, способом організації їі професійної діяльності й узгодженням (C) Prymachok Liudmyla

DOI (article): https://doi.org/10.32626/2227-6246.2019-46.327-347 
останньої з реальними або ідеальними соціальними умовами. До таких протиріч належать: з одного боку - протиріччя між здібностями, індивідуальністю, потребами особистості, з іншого - протиріччя між вимогами суспільства й умовами реального життя; потреби між генетично закладеними прагненнями та бажаннями особистості, їі потенціалами i ступенем їхньої реалізації, якого вдалося досягти в даний період часу. Також мають місце протиріччя між домаганнями, зусиллями і настановами особистості та результатами професійної діяльності. У свою чергу, розв'язуючи окреслені протиріччя, особистість досягає зрілості, а її суб'єктні якості та характеристики можна вважати сформованими.

Наступний, другий, критерій суб'єктності - це свобода використання зовнішніх і внутрішніх умов своєї життедіяльності, здатність до вибудовування соиіальних та особистісних взаєлостосунків, які оптилальною мірою фасилітують розвиток особистості (Титов, 1995). Третій критерій - наявність срорлованої, гарлонійної «Я-концепиї̈» (Титов, 1995), що ми вважаємо основою суб’єктності фахівця з фізичної реабілітації.

Характеризуючи суб'єктність особистості, С. Л. Рубінштейн (Рубинштейн, 1999) до її структури включив три параметри: чого хоче людина (iї потреби, мотиви, домагання), що

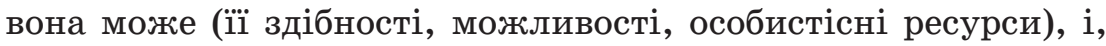
нарешті, що вона із себе представляє (iї світогляд, характер тощо). Слід зазначити, що особистісні протиріччя суб’єкта перетворюватимуться в протиріччя із соціумом, якщо бажання людини не відповідатимуть здібностям, а характер індивіда не дозволятиме йому використовувати здібності в напрямку реалізації власних бажань. Гармонізація цих особистісних складових, у свою чергу, забезпечує функціонування так званих «надможливостей» суб'єкта.

Розвиток суб'єктності припускає аналіз цього процесу як системного, за умов існування якого усі характеристики суб'єкта розглядатимуться у взаємозв'язку всіх компонентів (C) Prymachok Liudmyla DOI (article): https://doi.org/10.32626/2227-6246.2019-46.327-347 
структури особистості, в постійному розвитку та русі тощо. Крім того, аналіз суб’єктності припускає також здійснення інтегративного підходу до цього явища, що дає змогу вивчати потенційний і реальний розвиток фахівця з фізичної реабілітації як суб'єкта професійної діяльності, визначає стратегії розвитку спеціаліста, розглядає реабілітолога як цілісну, гармонійну особистість, розвиток якої забезпечуватиметься взаємодією внутрішніх ресурсів і потенціалів, можливостями професійного середовища і самої особистості фахівця 3 фізичної реабілітації, особливостями творення нових властивостей i характеристик, які, в свою чергу, фасилітують формування фахівця як суб'єкта професійної діяльності. Застосування суб’єктного підходу щодо дослідження процесу професійного становлення реабілітолога дає можливість аналізувати його як процес, що актуалізує високий рівень активності суб'єктів, які беруть участь у професійній діяльності загалом, цілеспрямованість професійної діяльності особистості, яка прагне до розвитку власне професійної компетентності. Останне, в свою чергу, сприяе реорганізації та якісному перетворенню необхідних для здійснення успішної професійної діяльності психічних і особистісних властивостей реабілітолога, подальшого їх використання як ресурсів $\mathrm{i}$ потенціалів відповідно до вимог та умов професійної діяльності такого фахівця.

Необхідно також зазначити, що поняття суб'єктності має свої рівні сформованості. Так, у науковій літературі (Роменець, 1993; Слободчиков, 1994) описано декілька рівнів розвитку суб'єктності: досуб'єктний, суб'єктно-нестійкий, суб'єктно-орієнтаційний, суб'єктно-професійний тощо. Завдяки цьому можна уявити загальну логіку суб'єктного становлення з урахуванням конкретних професійно значущих умов, що характеризуватимуть рівні розвитку суб'єктності фахівця.

Отже, реабілітолога можна розглядати як суб'єкта власного розвитку. Порівнюючи себе з іншими, цей суб'єкт може (c) Prymachok Liudmyla

DOI (article): https://doi.org/10.32626/2227-6246.2019-46.327-347 
активно змінювати і формувати свої життєві цінності й, тим самим, створювати нові умови для власне індивідуального розвитку. Особистість реабілітолога є системною характеристикою, включеною до ширших систем, таких як суспільство, соціальна група тощо. Відтак, реабілітолог, користуючись потенціалом розвитку суспільних або соціальних груп, ніби «прориває» межі власної системності, створюючи нові системи, збагачені та вдосконалені.

Для нашого дослідження важливо врахування того, що для формування реабілітолога як суб'єкта професійної діяльності корисна думка представників гуманістичної психології про те, що сутність розвитку людини - прагнення реалізувати у процесі життєдіяльності свій вроджений потенціал, а головним у розвитку особистості є її самоактуалізація (Maslow, 1971; Rogers, 1983). Проте, з точки зору раціогуманістичної психології, парадигми якої ми дотримуємося в нашому дослідженні, важливими для становлення реабілітолога як професіонала є не тільки процеси самоактуалізації та самореалізації, але й спрямованість особистості. При цьому слід наголосити, що головним змістом професійного розвитку повинна стати прогресивна і гуманістична (а не егоїстична) самоактуалізація і самореалізація особистості. Для психології, яка орієнтує особистість на раціогуманістичний напрямок розвитку, близькими є ідеї Г. О. Балла (Балл, 1996), який наголошував, що рівень розвитку фахівця як професіонала великою мірою визначається тим, наскільки результати професійної діяльності суб'єкта прийнятні для інших.

Отже, вимоги до суб'єктів медичної сфери діяльності значною мірою визначаються характером і змістом професійної діяльності й мають свої специфічні особливості. При цьому важливо зазначити, що суб'єктність фахівця - досить важлива характеристика саме тому, що його професійна діяльність є так званою «соціальною діяльністю». На відміну від інших видів професійної діяльності, спрямованих на перетворення матеріального світу речей, професійна діяльність (C) Prymachok Liudmyla DOI (article): https://doi.org/10.32626/2227-6246.2019-46.327-347 
DOI: https://doi.org/10.32626/2227-6246.2019-46

фахівця з фізичної реабілітації спрямована не на предмети, а на індивідів як таких, і за свій об'єкт дослідження визначає взаємостосунки фахівця з пацієнтами. Функціональним призначенням професійної діяльності реабілітолога є також регуляція цих взаємостосунків, істотне управління цими відносинами, в тому числі - в різних сферах і на різних рівнях суспільства.

Це означає, що професійна діяльність фахівця з фізичної реабілітації передбачає досить чітку, соціально прийнятну форму взаємостосунків одного суб'єкта з іншим / іншими, яка здійснюється у спосіб, визначений фахівцем. Особливістю професійної діяльності реабілітолога $є$ те, що за своєю суттю вона є системною. Це означає, що професійні рішення, які приймаються в одних сферах цієї професійної системи, впливають на рішення, які приймаються в інших. При цьому професійні рішення повинні враховувати багато чинників, у тому числі - психологічних, які, з одного боку, є дещо інертними, а з іншого - реактивними. У зв'язку з цим, як визнають спеціалісти, теорія і практика здійснення фізичної реабілітації в сучасних умовах складається на основі реально діючих і постійно мінливих суспільних процесів і явищ та, водночас, постає у вигляді відносно жорсткого, одномірного процесу управління, який практично не враховує психологічні зміни соціуму. Останнє, в свою чергу, може призвести до складних наслідків розвитку медичної сфери в українському суспільстві.

Розглянемо більш детально найважливіші характеристики суб'єктності особистості фахівця з фізичної реабілітації. Однією з таких характеристик є активність особистості. Активність - це інтегральний спосіб самовираження суб'єкта. Вона має свої форми експлікації, виражені в ініціативі, відповідальності, семантичній презентації власне особистісних домагань, саморегуляції як способі організації та здійсненні професійної діяльності. Активність пов'язана із саморухом, саморегуляцією у ставленні людини до соціокультурної ре(c) Prymachok Liudmyla

DOI (article): https://doi.org/10.32626/2227-6246.2019-46.327-347 
альності й означає переважаючу роль внутрішніх умов детермінації професійної діяльності над зовнішніми i, відповідно, має на увазі їхню інтеграцію відповідно до професійного статусу реабілітолога, до функцій його професійної діяльності тощо. Особистісні потенціали фахівця з фізичної реабілітації досить по-різному ініціюють прояви індивідуальної поведінки суб'єкта в професійній діяльності. Аналіз реабілітолога як суб'єкта професійної діяльності у процесі самопізнання, саморозвитку, самовдосконалення, відповідно, великою мірою підвищує значущість особистісних потенціалів, завдяки яким актуалізуються «цілісність», «гармонійність", «самобутність» фахівця. Сутність суб'єктності виявляється в поєднанні усіх властивостей, якостей і особливостей, притаманних особистості. Так, М. В. Зубакин і Л. Я. Дорфман (Зубакин \& Дорфман, 2014) вважають, що до суб’єктності слід підходити як до процесу інтеграції всіх властивостей, якостей, характеристик людини як суб'єкта професійної діяльності й цілісної, сформованої особистості. Розвиваючи це положення, Б. Г. Ананьєв писав: «Для того, щоб підійти до проблеми індивідуального цілого, потрібно уявити людину не тільки як відкриту систему, але і як систему «закриту», замкнену внаслідок внутрішнього взаємозв'язку її властивостей (як особистості, індивіда, суб’єкта)» (Ананьев, 1969: 62). Найповніше інтеграція «відкритого» i «закритого» змісту представлена в розробленій К. К. Платоновим (Платонов, 2005) структурі особистості. Учений виокремлює психічні утворення і психічні процеси різних рівнів: спрямованість (потяги, бажання, інтереси, нахили, ідеали, переконання, світогляд, потреби, мотиви тощо); досвід (знання, вміння, навички, звички, індивідуальна культура); функціональні особливості психічних процесів (емоції, сприйняття, пам'ять, мислення, увага, воля); типологічні особливості вищої нервової діяльності (темперамент, вікові й статеві особливості, специфіка енергетичних i регуляторних функцій організму тощо). Існують й інші характеристики суб'єктності, описані,

(C) Prymachok Liudmyla

DOI (article): https://doi.org/10.32626/2227-6246.2019-46.327-347 
зокрема, у працях О. Г. Ковальова (Ковалёв, 1989), Б. Ф. Ломова (Ломов, 1984), В. М. Мясищева (Мясищев, 1970) та ін. Загальним для цих теорій є те, що в розроблених ученими системах наголошується на багатомірних зв'язках між різними підсистемами, а особливості психічних процесів характеризуються різними формами відображення і регуляції поведінки.

Отже, говорячи про суб’єкт і, зокрема, про суб'єкт професійної діяльності, ми матимемо на увазі його співвіднесення із соціальними і психічними явищами, вважаючи, що на них можна впливати і ними можна керувати з урахуванням індивідуально-психологічних і психофізіологічних особливостей, нейродинамічних властивостей психіки, психічних процесів і станів, потреб та інтересів, мотивів і цінностей, переконань і світоглядних орієнтацій, розвинених якостей і сформованих здібностей, професійних знань, умінь, навичок, індивідуальних проявів особистості, стилів професійної діяльності, притаманних тільки цьому суб'єктові.

3 урахуванням теоретико-методологічного аналізу суб’єкта професійної діяльності та суб'єктності особистості фахівця виокремимо аспекти, що характеризують суб’єктність сале фахівия з фізичної реабілітаиї. Так, ми вважаємо, що можна виокремити три аспекти: 1) соціальний - пов'язаний із проявами суб'єкта з точки зору соціальної ідентичності, носія соціальних норм, ставлень і особливостей взаємодій; 2) аклеологічний, пов'язаний із характеристиками, які виявляються суто в професійній діяльності, в тому числі - у спеціальній, спрямованій на розвиток професійної компетентності фахівця; 3) аксіологічний аспект, спрямований на становлення аксіопсихіки фахівця з фізичної реабілітації.

Суб’єктні властивості у структурі особистості реабілітолога визначатимуть цілеспрямоване формування ключових компетентностей професіоналів: прагнення до самопізнання і набуття ідеального «образу Я»; розширення варіативності використання духовного потенціалу особистості (через (C) Prymachok Liudmyla

DOI (article): https://doi.org/10.32626/2227-6246.2019-46.327-347 
мистецтво, літературу тощо); орієнтація на культивування духовності як професійної якості реабілітолога; розширення інформаційної бази і свободи вибору знання; зростання інтересу до знань культурної спадщини етносу і держави, до діалогу культур. Фахівець із фізичної реабілітації, який усвідомлює сутність своєї професійної діяльності, співвідносить свої особистісні якості та характеристики з вимогами професійної діяльності, юридичними нормами, морально-етичними принципами тощо. Завдяки цьому фахівець великою мірою перебуває в позиції необхідності створення умов для саморозгортання свого внутрішнього духовного потенціалу, пошуку істини з урахуванням моральних основ професійної діяльності; підтримки творчих прагнень і знаходження індивідуальних форм реалізації власне особистісних потенціалів. Також слід зауважити, що аксіологічний аспект суб'єктності наголошує на побудові певної картини світу, образу світу, самоставлення фахівця, його світоглядної життєвої позиції. В основу сформованості аксіологічного аспекту суб'єктності реабілітолога покладено найвищий рівень розвитку ціннісних орієнтацій та етично-смислових фреймів особистості.

Нами зазначено, що базовими якостями суб'єктності реабілітолога є креативне мислення і самостійна світоглядна життєва позиція. Основою креативного мислення є здатність індивіда до системного аналізу явищ, а підгрунтям самостійної світоглядної життєвої позиції - оптимальна внутрішня свобода особистості. Поряд зі свободою творчості, зорієнтованістю на кінцевий, найбільшою мірою корисний результат і наявністю можливостей самовираження, вільне володіння практичними навичками також є основою формування оптимальної свободи особистості спеціаліста, що, зі свого боку, сприяє набуттю ним самостійної світоглядної життєвої позиції.

На нашу думку, саме культура креативного мислення і сформованість світогляду особистості є й аксіологічною базою професійної діяльності реабілітолога, основою віри паці-

(C) Prymachok Liudmyla DOI (article): https://doi.org/10.32626/2227-6246.2019-46.327-347 
DOI: https://doi.org/10.32626/2227-6246.2019-46

єнта в своє одужання, що здійснює неабияку терапевтичну дію на особистість.

Iз точки зору змістової характеристики суб'єктності в професійній діяльності реабілітолога можна виокремити чотири взаємопов'язані блоки: мотиваційно-иіннісний, інтениійно-діяльнісний, рефлексивно-регуляиійний, креативноопераиіональний. У межах кожного блоку експлікуються ті якості суб’єкта, що відповідають за функціонування і розвиток відповідної сфери особистості фахівця з фізичної реабілітації (табл. 1).

\section{таблищя 1}

Блоки професійної діяльності фахівця з фізичної реабілітації з урахуванням характеристик суб’єктності спеціаліста

\begin{tabular}{|c|c|c|c|}
\hline \multicolumn{4}{|c|}{ Блоки професійної діяльності реабілітолога } \\
\hline $\begin{array}{c}\text { Мотиваційно- } \\
\text { ціннісний }\end{array}$ & $\begin{array}{l}\text { Інтенційно- } \\
\text { діяльнісний }\end{array}$ & $\begin{array}{c}\text { Рефлексив- } \\
\text { но-регуля- } \\
\text { ційний }\end{array}$ & $\begin{array}{c}\text { Креативно- } \\
\text { операціо- } \\
\text { нальний }\end{array}$ \\
\hline Мотиви і цілі & Актуалізація скла- & Професійна & Якості та \\
\hline професійної & професій- & рефлексія, & можливості \\
\hline діяльності як & ної діяльності, її & к р и ти чн а & професійно- \\
\hline смисло- і ці- & структурних скла- & оцінка про- & го розвитку, \\
\hline леутворюючі & дових; здатність до & ф е с і й н и х & самовдоско- \\
\hline детермінан - & розв'язання про- & знань, умінь & налення \\
\hline ти; структура & фесійних завдань i & i навичок, & особистісно- \\
\hline ціннісних орі- & задач, здійснення & оцінка реа- & го зростання \\
\hline єнтацій, цін- & контролю й оцінки & білітологом & \\
\hline ності самороз- & професійної діяль- & власної про- & \\
\hline витку в ієрар- & ності, здатність до & фесійної ді- & \\
\hline хії цінностей & співпраці, бачення & яльності & \\
\hline олога & унікальності іншої & & \\
\hline & людини, активність & & \\
\hline & у налагодженні & & \\
\hline & контактів і взаємос- & & \\
\hline & тосунків з іншими & & \\
\hline
\end{tabular}

(C) Prymachok Liudmyla

DOI (article): https://doi.org/10.32626/2227-6246.2019-46.327-347 
Отже, лотиваційно-ціннісний блок уміщує мотиви і цілі професійної діяльності реабілітолога, а також структуру цінностей фахівця.

Інтенційно-діяльнісний блок характеризується поєднанням таких структурних складових: здатностей і здібностей реабілітолога до розв'язання професійних завдань і задач; здатності до співпраці, бачення унікальності іншої людини, активності в налагодженні контактів.

Рефлексивно-регуляиійний блок пов'язаний із професійною рефлексією, критичною оцінкою професійних знань 3 огляду на особливості реальної професійної діяльності фахівця з фізичної реабілітації.

Креативно-операціональний блок містить особистісні якості та можливості професійного розвитку і самовдосконалення.

Так, змістові характеристики суб’єктності фахівця з фізичної реабілітації, можливості професійного розвитку і самовдосконалення ніби «нашаровуються» на індивідуальні й особистісні якості реабілітолога. Також наголосимо на найбільш значущих для суб’єктності реабілітолога характеристиках.

Перш за все, слід сказати про особистісну свободу, яка характеризує необмеженість можливостей людини, її незалежність від об'єктивних характеристик зовнішнього середовища й особливостей їх активного подолання. Серед суб'єктних характеристик реабілітолога особистісна свобода є однією 3 необхідних характеристик, оскільки саме ця ознака вирізняє творчу форму активності фахівця від тієї, що має місце за умов відсутності вибору. Найвищим рівнем особистісної свободи є свобода творчості, завдяки якій з'являється можливість не стільки обирати із запропонованих форм і методів професійної діяльності, скільки творити нові. Суб’єктна активність і внутрішня свобода фасилітують формування особистості, яка суттєво відрізняється від інших, і зумовлюють їі унікальність.

(C) Prymachok Liudmyla

DOI (article): https://doi.org/10.32626/2227-6246.2019-46.327-347 


\section{Висновки}

Якісною характеристикою суб'єктності фахівця з фізичної реабілітації є суб’єктність різноманітних особистісних взаємостосунків, що складаються в професійній діяльності. Це, насамперед, суб'єктність професійного суспільного управління, яка вибудовується в суб'єкт-суб'єктній парадигмі; суб'єктність взаємостосунків на рівні різних соціальних і професійних груп, включаючи взаємостосунки на рівні індивідуального, особистісного спілкування, які також повинні вибудовуватися в суб'єкт-суб'єктній парадигмі.

До якостей суб'єктності фахівця з фізичної реабілітації, які мають для цього спеціаліста неабияке значення, належить також відповідальність. Відповідальність означає здатність реабілітолога гарантувати результат здійснення професійної діяльності в певні терміни на якісному рівні, не дивлячись на непередбачувані труднощі й протиріччя.

Відповідальність реабілітолога є одним з основних показників аксіологічності цього виду діяльності, оскільки суб'єкт повинен бути відповідальним не тільки перед самим собою, але й перед соціальним співтовариством (численними суспільними об'єднаннями), а найголовніше - перед суспільством загалом. У сфері фізичної реабілітації відповідальність нерідко трансформується в психотерапевтичну відповідальність.

У широкому розумінні психотерапевтична відповідальність - це, передусім, добровільне прийняття доцільного 3 точки зору реабілітолога рішення. Чинник добровільності означає, що суб’єкт самостійно, з огляду на свої переконання, спрямовує свою волю, свої особистісні ресурси на реалізацію прийнятого рішення. Узяти на себе психотерапевтичну відповідальність означає зайняти відповідну позицію, ставити і розв'язувати професійні завдання та задачі з високим ступенем ефективності.

Психотерапевтична відповідальність набуває проективного характеру, тобто актуалізує бажання реабілітолога до(c) Prymachok Liudmyla

DOI (article): https://doi.org/10.32626/2227-6246.2019-46.327-347 
сягти бажаного результату. Також важливою детермінантою професійного становлення фахівця 3 фізичної реабілітації $€$ рефлексія (здатність до відрефлексування власної діяльності), сутність якої проаналізуємо в наступних наших публікаціях.

\section{Література}

Абульханова К. А. Психология и сознание личности (проблемы методологии, теории и исследования реальной личности): Избранные психологические труды. Москва : Московский психолого-социальный институт; Воронеж : Издательство НПО «МОДЭК», 1999. 224 с.

Ананьев Б. Г. Человек как предмет познания. Ленинград : Изд-во Ленинградского ун-та, 1969. 339 с.

Балл Г. О. Про психологічний зміст вільного розвитку особистості. Психологічні аспекти гуманізації освіти: Книга для вчителя / за ред. Г. О. Балла. Київ - Рівне, 1996. С. 53-67.

Брушлинский А. В. Субъектно-деятельностная концепция и теория функциональных систем. Вопросы психологии. 1999. № 5. С. 110-121.

Зубакин М. В., Дорфман Л. Я. Я-концепция, личность и восприятие сцен насилия (на материале художественных кинофильмов). Вестник Южно-Уральского государственного университета. Серия «Психология». 2014. Т. 7. № 2. С. 5-14.

Ковалёв Г. А. О системе психологического воздействия: психология воздействия. Москва : Наука, 1989. 368 с.

Котик I. О. Розвиток суб' єктності учнів при розв'язанні конфліктів у процесі діалогічного навчання. Психологія: Збірник наукових пращь НПУ ім. М. П. Драгоманова. Київ, 2000. Вип. 3 (10). С. 143-150.

Ломов Б. Ф. Методологические и теоретические проблемы психологии / отв. ред. Ю. М. Забродин, Е. В. Шорохова. Москва : Наука, 1984. $444 \mathrm{c}$.

Михальчук Н. О. Діалогічна взаємодія школярів з іншомовним текстом в детермінації становлення іх суб'єктності. Оновлення змісту, форм та методів навчання і виховання в закладах освіти: Зб. наук. праць «Наукові записки РДГУ». Рівне, 2008. Вип. 41. C. $127-133$.

Мясищев В. Н. О взаимосвязи общения, отношения, отражения как проблеме общений и социальной психологии: социально-психологические и лингвистические характеристики форм общения и развития контактов между людьми. Ленинград : Педагогика, 1970. $185 \mathrm{c}$.

(C) Prymachok Liudmyla

DOI (article): https://doi.org/10.32626/2227-6246.2019-46.327-347 
Онуфрієва Л. А. Проблема розвитку особистості професіонала у сучасних дослідженнях. Проблеми емпіричних досліджень в психології: Матеріали VII міжнародної науково-практичної конферениї (5-6 грудня 2013 р., м. Київ) / за ред. I. В. Данилюка, I. В. Ващенко. Київ : ОВС, 2013. Вип. 1. С. 204-209.

Платонов К. К. Мои личные встречи на великой дороге жизни (воспоминания старого психолога). Москва : Институт психологии РАН, 2005. $310 \mathrm{c}$.

Роменець В. А. Суб'єкт психічної активності як предмет історичної психології. Психологія суб’єктної активності особистості. Київ : Ін-т психології ім. Г. С. Костюка АПН України, 1993. С. 81-82.

Рубинштейн С. Л. Основы общей психологии. Санкт-Петербург : Питер, 1999. $720 \mathrm{c.}$

Слободчиков В. И. Реальность субъективного духа. Человек. 1994. № 5. C. 21-38.

Титов В. М. Історичні форми суб'єктності та їх розвиток в європейській культурі. Психологічні проблели навчання, виховання, активності та розвитку особистості: Матеріали звітної наукової сесї Інституту психологї АПН України (10-11 лютого 1994 р.). Київ, 1995. С. 239-246.

Hoffman, L. (1961). Cognitions for creative problem solving. Journal of Experimental Psychology, 52, 2, 83-89.

Maslow, A. N. (1971). The father reaches of human nature. New York : Viking press. $423 \mathrm{p}$.

Rogers, C. R. (1983). Freedom to learn for the 80'S. Columbus etc. : Charles E. Merril Publ. Co. 312 p.

\section{References}

Abulkhanova, K.A. (1999). Psikhologiia i soznanie lichnosti (problemy metodologii, teorii $i$ issledovaniia realnoi lichnosti): Izbrannye psikhologicheskie trudy [Psychology and consciousness of the person (problems of the methodology, the theory and research of a real person): Selected psychological issues]. Moskva : Moskovskii psikholoho sotsialnyi institut; Voronezh : Izdatelstvo NPO «MODEK» [in Russian].

Ananiev, B.G. (1969). Chelovek kak predmet poznaniia [The man as a subject of knowledge]. Leningrad: Izd-vo Leningradskoho Universiteta [in Russian].

Ball, G.O. (1996). Pro psykholohichnyi zmist vilnoho rozvytku osobystosti [On the psychological content of free growth of a personality]. H.O. Ball [Eds.] Psykholohichni aspekty humanizatsii osvity: Knyha dlia vchytelia - Psychological aspects of the humanization of education: A book for a teacher (pp. 53-67). Kyiv-Rivne [in Ukrainian].

(C) Prymachok Liudmyla

DOI (article): https://doi.org/10.32626/2227-6246.2019-46.327-347 http://journals.uran.ua/index.php/2227-6246 
Brushlinskiy, A.V. (1999). Subektno-deiatelnostnaia kontseptsiia i teoriia funktsionalnykh sistem [Subjective activity conception and theory of functional systems]. Voprosy psikhologii - Psychology Issues, 5, 110121 [in Russian].

Zubakin, M.V. \& Dorfman, L.Ya. (2014). Ya-kontseptsiia, lichnost i vospriiatie stsen nasiliia (na materiale khudozhestvennykh kinofilmov) [Self-conception, a personality and the perception of scenes of violence (based on feature films)]. Vestnik Yuzhno-Uralskogo gosudarstvennogo universiteta - Bulletin of the South Ural State University. Series «Psychology», 7 (2), 5-14 [in Russian].

Kovaliev, G.A. (1989). O sisteme psikhologicheskogo vozdeistviia: Psikhologiia vozdeistviia [About the system of psychological impact: Psychology of impact]. Moskva : Nauka [in Russian].

Kotyk, I.O. (2000). Rozvytok subiektnosti uchniv pry rozviazanni konfliktiv u protsesi dialohichnoho navchannia [The development of students' subjectivity in conflicts' resolution during dialogical process of training]. Psykholohiia. Zbirnyk naukovykh prats NPU im. M.P. Drahomanova - Psychology. Collection of Scientific Papers of Drahomanov NPU, 3(10), 143-150. Kyiv [in Ukrainian].

Lomov, B.F. (1984). Metodologicheskie i teoreticheskie problemy psikhologii [Methodological and theoretical problems of psychology]. Yu.M. Zabrodin, E.V. Shorokhova [Eds.]. Moskva : Nauka [in Russian].

Mykhalchuck, N.O. (2008). Dialohichna vzaiemodiia shkoliariv z inshomovnym tekstom v determinatsii stanovlennia yikh subiektnosti [Dialogical interaction of pupils with foreign language texts in the determination of the growth of their subjectivity]. Onovlennia zmistu, form ta metodiv navchannia $i$ vykhovannia $v$ zakladakh osvity: $Z$ b. nauk. prats «Naukovi zapysky RDHU» - Updating the content, forms and methods of education and upbringing in educational institutions: Collection of research papers "Scientific Issues of Rivne State University of the Humanities, 41, 127-133. Rivne [in Ukrainian].

Myasishchev, V.N. (1970). O vzaimosviazi obscheniia, otnosheniia, otrazheniia kak probleme obschenii i sotsialnoi psikhologii: Socialno-psikhologicheskie i lingvisticheskie kharakteristiki form obscheniia i razvitiia kontaktov mezhdu liudmi [About the connection of communication, attitude, reflection as a problem of communication and social psychology: Socio-psychological and linguistic characteristics of forms of communication and the development of contacts between people]. Leningrad : Pedagogika [in Russian].

Onufriieva, L.A. (2013). Problema rozvytku osobystosti profesionala u suchasnykh doslidzhenniakh [The problem of the development of a pro-

(C) Prymachok Liudmyla

DOI (article): https://doi.org/10.32626/2227-6246.2019-46.327-347 
DOI: https://doi.org/10.32626/2227-6246.2019-46 2019. Випуск 46

fessional in contemporary researches]. I.V. Danyliuk, I.V. Vashchenko [Eds.]. Problemy empirychnykh doslidzhen v psykholohii - The Problems of Empirical Researches in Psychology : Proceedings of VII International Scientific and Practical Conference, 1, 204-209. Kyiv : OVS [in Ukrainian].

Platonov, K.K. (2005). Moi lichnye vstrechi na velikoi doroge zhizni (vospominaniia starogo psikhologa) [My personal meetings on the great road of life (memories of an old psychologist)]. Moskva : Institut Psikhologii RAN [in Russian].

Romenets, V.A. (1993). Subiekt psykhichnoi aktyvnosti yak predmet istorychnoi psykholohii [The subject of mental activity as a subject of historical psychology]. Psykholohiia subiektnoi aktyvnosti osobystosti - Psychology of subjective activity of a personality. (pp. 81-82). Kyiv : In-t Psycholohii im. H.S. Kostiuka APN Ukrainy [in Ukrainian].

Rubinstein, S.L. (1999). Osnovy obschei psikhologii [Fundamentals of General Psychology]. St. Petersburg : Peter [in Russian].

Slobodchikov, V.I. (1994). Realnost subektivnogo dukha [The reality of subjective spirit]. Chelovek - A Human, 5, 21-38 [in Russian].

Titov, V.M. (1995). Istorychni formy subiektnosti ta yikh rozvytok v yevropeiskii kulturi [Historical forms of subjective's activity and their development in European culture]. Psykholohichni problemy navchannia, vykhovannia, aktyvnosti ta rozvytku osobystosti - Psychological problems of studying, upbringing, activity and development of a personality : Proceedings of a scientific session of the Institute of Psychology of the Academy of Pedagogical Sciences of Ukraine. (pp. 239-246). Kyiv [in Ukrainian].

Hoffman, L. (1961). Cognitions for creative problem solving. Journal of Experimental Psychology, 52, 2, 83-89.

Maslow, A.N. (1971). The father reaches of human nature. New-York : Viking press.

Rogers, C.R. (1983). Freedom to learn for the 80'S. Columbus etc. : Charles E. Merril Publ. Co.

\section{Примачок Людмила. Суб'єктність як необхідна складова професійного становлення фахівця з фізичної реабілітації}

\section{АНОТАЦІЯ}

У статті описано рівні срормованості суб'єктності індивіда. Окреслено роль суб'єктності в професійній діяльності фахівця з фізичної реабіліта(C) Prymachok Liudmyla

DOI (article): https://doi.org/10.32626/2227-6246.2019-46.327-347 
ції. Визначено найважливіші характеристики суб'єктності особистості фахівия з фрізичної реабілітації. Сформульовано аспекти суб'єктності саме фрахівця з фізичної реабілітації: 1) соціальний - пов'язаний із проявами суб'єкта з точки зору сочіальної ідентичності, носія соціальних норм, ставлень і особливостей взаємодій; 2) акмеологічний - пов'язаний із характеристиками, що виявляються суто у професійній діяльності, в тому числі - у спеціальній, спрямованій на розвиток профресійної компетентності фахівия; 3) аксіологічний аспект, спрямований на становлення аксіопсихіки фрахівия з фізичної реабілітації.

Із точки зору змістової характеристики суб'єктності виокремлено чотири взаємопов'язані блоки в професійній діяльності реабілітолога, розкрито їхній зміст. Зазначено, що мотиваційно-ціннісний блок уміщує мотиви і цілі професійної діяльності реабілітолога, а також структуру цінностей фахівця. Наголошено, що інтенційно-діяльнісний блок характеризується поєднанням таких структурних складових: здатностей i здібностей реабілітолога до розв'язання професійних завдань і задач; здатності до співпраці, бачення унікальності іншої людини, активності в налагодженні контактів. Підкреслено, що рефлексивно-регуляційний блок пов'язаний із професійною рефлексією, критичною оцінкою професійних знань з огляду на особливості реальної професійної діяльності фрахівця з фізичної реабілітації. зазначено, що креативно-операціональний блок містить особистісні якості та можливості професійного розвитку і самовдосконалення.

У статті уточнено поняття «психотерапевтична відповідальність» фахівця з фізичної реабілітації. Зазначено, що в широкому розумінні психотерапевтична відповідальність - че, передусім, добровільне прийняття доцільного з точки зору реабілітолога рішення. Наголошено, що чинник добровільності означає, що суб'єкт самостійно, з огляду на свої переконання, спрямовує свою волю, свої особистісні ресурси на реалізацію прийнятого рішення. Підкреслено, що взяти на себе психотерапевтичну відповідальність означає зайняти відповідну позицію, ставити $і$ розв'язувати професійні завдання та задачі з високим ступенем ефективності.

Ключові слова: суб'єктність, професійна діяльність, сочіальний аспект, акмеологічний аспект, аксіологічний аспект, мотиваційно-ціннісний блок, інтенційно-діяльнісний блок, рефлексивно-регуляційний блок, креативно-операціональний блок, психотерапевтична відповідальність.

(C) Prymachok Liudmyla

DOI (article): https://doi.org/10.32626/2227-6246.2019-46.327-347 
DOI: https://doi.org/10.32626/2227-6246.2019-46

Примачок Людмила. Субъектность как необходимая составляющая профессионального становления специалиста по физической реабилиmaцuи

\section{АННОТАЦИЯ}

В статье описаны уровни сформированности субъектности индивида. Определена роль субъектности в профессиональной деятельности специалиста по физической реабилитации. Дана характеристика наиболее важных особенностей субъектности личности специалиста по физической реабилитации. Сформулированы аспекты субъектности именно специалиста по физической реабилитации: 1) социальный - связан с проявлениями субъекта с точки зрения социальной идентичности, носителя социальных норм, отношений и особенностей взаимодействий; 2) акмеологический - имеет непосредственное отношение кхарактеристикам, которые оказываются исключительно важными в профессиональной деятельности, в том числе - в специальной, направленной на развитие профессиональной компетентности специалиста; 3) аксиологический аспект, направленный на становление аксиопсихики специалиста по физической реабилитации.

С точки зрения содержательной характеристики субъектности выделены четыре взаимосвязанных блока в профессиональной деятельности реабилитолога, раскрыто их содержание. Отмечено, что мотивационно-ценностный блок включает мотивы и цели профессиональной деятельности реабилитолога, а также структуру ценностей специалиста. Отмечено, что интенционально-деятельностный блок характеризуется сочетанием таких структурных составляющих: способностей и возможностей реабилитолога к решению профессиональных заданий и задач; способностей к сотрудничеству, пониманию уникальности другого человека, активности в налаживании контактов. Подчеркнуто, что рефлексивно-регулячионный блок связан с профессиональной рефлексией, критической оценкой профессиональных знаний; данный блок учитывает особенности реальной профрессиональной деятельности специалиста по физической реабилитации. Отмечено, что креативно-операциональный блок актуализирует личностные качества и возможности профессионального развития и самосовершенствования.

В статье уточнено понятие «психотерапевтическая ответственность» специалиста по физической реабилитации. Отмечено, что в ши(c) Prymachok Liudmyla

DOI (article): https://doi.org/10.32626/2227-6246.2019-46.327-347 http://journals.uran.ua/index.php/2227-6246 
DOI: https://doi.org/10.32626/2227-6246.2019-46 2019. Випуск 46

роком смысле психотерапевтическая ответственность - это, прежде всего, добровольное принятие целесообразного, с точки зрения реабилитолога, решения. Отмечено, что фактор добровольности означает, что субъект самостоятельно, учитывая свои убеждения, направляет свою волю, свои личностные ресурсы на реализацию принятого решения. Подчеркнуто, что взять на себя психотерапевтическую ответственность означает занять соответствующую позицию, ставить и решать профессиональные задания и задачи с высокой степенью эффрективности.

Ключевые слова: субъектность, профессиональная деятельность, социальный аспект, акмеологический аспект, аксиологический аспект, мотивационно-ценностный блок, интенционально-деятельностный блок, рефрлексивно-регуляционный блок, креативно-операциональный блок, психотерапевтическая ответственность.

Original manuscript received September 09, 2019 Revised manuscript accepted September 28, 2019 